\title{
HOW TO MEASURE FATIGUE AMONG PILOTS?³
}

\begin{abstract}
Fatigue represents a major problem in aviation. Therefore, it is important to identify fatigue among pilots early enough before an incident or an accident occurs. The aim of our study has been to conduct a literature review on measurements of fatigue among pilots; to find out which measurements are used to recognize fatigue and what the results of conducted studies are with the focus on the usefulness of tests for measuring fatigue. The findings are based on meta-analysis. For the purpose of our study, we have used electronic databases Google Scholar, Emerald, MedLit and Academic Search Complete. The content analysis of the articles has been used to summarize and compare qualitative data. The results obtained show that tests for measuring fatigue can be divided into two groups, objective tests and subjective tests. Pilots' subjective fatigue is mostly evaluated using Samn-Perelli fatigue scale, which is widely used in the aviation industry and it provides data for comparison. The contribution of our study is the widened understanding of fatigue measuring and usefulness of these measurements among pilots. The findings of our research are descriptive in nature. Further studies should be focused on deeper investigation of this topic and could include case studies of fatigue among pilots with qualitative data.
\end{abstract}

Key words: pilots, fatigue, measuring fatigue, tests, human resource management

\section{INTRODUCTION}

Fatigue is a major cause of flight accidents (Ma et al., 2014) and therefore it represents a major problem in aviation (Petrie, Dawson, 1997). According to Taneja (2007) almost three quarters of pilots consider fatigue as a widespread problem in aviation. In comparison, Caldwel (2005) found out that $75 \%$ of pilots acknowledge fatigue as a major problem in job and Petrie et al. (2004) in their study determined that $64 \%$ of pilots reported to be fatigued due to their work. Factors that may cause fatigue are sleep loss, circadian rhythm disruption, shift work (Akerstedt, 1995; Taneja, 2007), cabin noise, vibrations, pressure changes (Ma et al., 2014), long working hours, crossing of time zones (van Drongelen, 2013), irregular duties (Petrie, Dawson, 1997), night flights, jet-lag, early wake-ups (Bourgeois-Bougrine et al., 2003).

Persistent fatigue can cause many problems, such as decreased short term memory, slowed reaction time, increased errors of omission, worsened mood (Mohler, 1966), difficulties in memory, making mistakes (Caldwell et al., 2009), health problems, impaired performance during work, and

\footnotetext{
1 Mag. Management, Ljubljanski potniški promet d.o.o., Celoveška cesta 160, 1000 Ljubljana, Slovenia. E-mail: andrej.jerman@lpp.si

2 PhD, Assistant Professor, University of Primorska, Faculty management, Cankarjeva 5, 6000 Koper, Slovenia. E-mail: maja.mesko@fm-kp.si

3 Received: 1 Novembar 2017; Accepted: 15 Decembar 2017
} 
decreased work-private life balance (van Drongelen, 2013). Symptoms of fatigue can be grouped into five categories, i.e. cognitive dysfunction (i.e. forgetfulness, loss of concentration, missing things, feeling mentally slow, easily distracted, careless, difficultly in planning, being confused, uncoordinated, clumsy), sleepiness, emotional disturbance (i.e. feel nervous, irritable, to withdraw and to become quiet), boredom and physical effects like sore eyes, sore muscles and feeling low energy (Petrie, Dawson, 1997). For this reason, it is important to identify fatigue among pilots early enough, before an incident or an accident occurs. There are many researches which investigate fatigue among pilots, but they are mostly focused on fatigue existence, rules about fatigue, causes and symptoms of fatigue, the relationship between fatigue and performance.

The aim of our study is to review psychological measurements of fatigue among pilots.

Hence, the purpose of this paper is to answer the following research questions:

RQ1: Which psychological measurements are used to recognize fatigue among pilots?

RQ2: What are the results of the studies with the focus on usefulness of tests for measuring fatigue?

The paper is structured as follows: the paper starts with the theoretical background of fatigue, as it has been given by different authors. The second section presents methodology. Finally, the main part where the research results are presented and discussed and the conclusion, including limitations and suggestions for future researches.

\section{FATIGUE AMONG PILOTS}

Safety flight requires effective performance without fatigue, i.e. without sleep loss, adverse circadian rhythm phase and workload factors (Wu, 2013). According to International Civil Aviation Organization (ICAO, 2011) fatigue is therefore defined "as a physiological state of reduced mental or physical performance capability resulting from sleep loss or extended wakefulness, circadian phase, or workload (mental and/or physical activity) that can impair a crew member's alertness and ability to safely operate an aircraft or perform safety-related duties."

Due to importance of fatigue, in 2011 new rules, shaped by strong fatigue research, were released by Federal Aviation Administration (FAA) regarding commercial passenger airline pilots (Lowry, 2012). The key components of the rules are: flight duty period, flight time limits, minimum rest period, varying flight and duty requirements, fitness for duty, cumulative flight duty and flight time limits and fatigue risk management system.

There are several researches dealing with fatigue among pilots, some of them are mentioned hereinafter.

Fatigue is closely related to the lack of sleep (Gilbert Tong, 2011). An average of eight hours of sleep per night is needed to maintain daytime alertness (Carskadon et al., 1982) and the way to recover sleep debt is sleep (Gilbert Tong, 2011).

High-fatigue pilots notice symptoms such as feeling irritable, nervous, and forgetful (emotional symptoms). Fatigue coping strategies used by pilots can be grouped into five different categories, 
i.e. active coping, planning energy use, mental withdrawal, communicating with other members of the crew, and drinking coffee. The most common strategies used among pilots are napping and conserving energy (Petrie \& Dawson, 1997). Stimulants are typically used to maintain alertness, while strategic naps maintain pilot performance and reduce sleep debt (Hatzler, 2014). Taneja (2007) found out that the most popular countermeasure is drinking tea or coffee (caffeine). In addition, van Drongelen et al. (2013) have described the trial evaluation of the effect of the intervention (tailored advice on exposure to daylight, sleep, physical activity and nutrition) on fatigue, sickness absence and health. The intervention can represent a practical tool in fatigue management.

Gander et al. (2013) examined whether longer flights result in greater sleepiness and fatigue and found that sleepiness ratings were lower and mean reaction speed was faster at the end of ultralong range flight and that the extended duration of ultra-long range flight did not lead to greater pilot fatigue. The study also suggests that because of multiple aspects of fatigue multiple fatigue measures should be used.

Powell et al. (2007) investigated which factors predicted fatigue and how important they were in prediction. He found out that fatigue in short-haul pilots was influenced by time of day, length of duty, the number of sectors flown, and airport of departure. In short haul flying, carried out by two-pilot, where there were no in-flight rest opportunities, resulted in higher fatigue levels (Eriksen et al., 2006). Powell et al. (2008) found out that the time of the day had an effect on fatigue. They also found out that fatigue increased with the length of duty and the number of sectors. Goode (2003) investigated the relationship between pilot schedules and accidents. He argued that the proportion of aviation accidents was in relationship with pilots having longer duty periods.

Since pilots' fatigue is clearly recognised as a significant risk factor for in-flight adverse events and currently there are no systems implemented in the cockpit to monitor, detect and react to pilot fatigue, the aim of our study has been to find out which measurements we can use for measuring fatigue among pilots.

\section{METHODOLOGY}

For the purpose of our study we used literature review focusing on pilots' fatigue and content analysis to summarize and compare qualitative data. The aim of qualitative research was not to come to conclusions that can be generalized, but to gain insight in a studied phenomenon. The literature review covers journal articles on fatigue among pilots. Firstly, key words were selected. The authors searched keywords: "fatigue" "measurement" and "pilots" and the following electronic databases were searched: Google Scholar, Emerald, MedLit, Academic Search Complete. Only peer-reviewed articles were included in the study. This approach resulted in 24 articles, published in a variety of journals and were read in full. In accordance with the aim of our research, which was to find out which psychological measurements were used to recognize fatigue and what the results of conducted studies were with the focus on the usefulness of tests for measuring fatigue, a content analysis process was applied. 10 peer-reviewed articles with psychological measurement about pilots' fatigue were found and included in the analysis. 


\section{A. Jerman, M. Meško: How to Measure Fatigue Among Pilots? Zbornik Veleučilišta u Rijeci, Vol. 6 (2018), No. 1, pp. 13-22}

From the text of each article authors obtained a table with the authors' names and the dates of publication of the article, a sample of the study, tests for measuring fatigue and main results of the study with the focus on usefulness of tests for measuring fatigue.

All of the articles, relevant for the content analysis, were examined by two independent researchers (authors of this paper), and coded according to the following steps:

- defining tests for measuring fatigue,

- defining main results of the study,

- $\quad$ defining usefulness of tests for measuring fatigue.

\section{RESULTS AND DISCUSSION}

We conducted literature review on measurements of fatigue among pilots in order to find out which measurements were used to recognize fatigue and what the results of conducted studies were with the focus on usefulness of tests for measuring fatigue.

To answer the research question, a synthetic representation of literature was provided. Firstly, research sample was described in short. After that we investigated tests for fatigue measuring in the research and presented main results. The literature review is shown in Table 1.

Table 1. The literature review of pilot fatigue measurements

\begin{tabular}{|c|c|c|c|}
\hline Authors, year of publication & Sample of the study & Measurement of fatigue & Main results \\
\hline Petrie and Dawson, 1997 & $\begin{array}{l}188 \text { pilots flying } \\
\text { Air New Zealand } \\
\text { International routes }\end{array}$ & $\begin{array}{l}\text { Vitality Scale } \\
\text { Self-constructed Fatigue } \\
\text { Questionnaire (symptoms, } \\
\text { coping strategies of } \\
\text { fatigue) }\end{array}$ & $\begin{array}{l}\text { The most common strategies for } \\
\text { coping with fatigue is napping and } \\
\text { conserving energy. Symptoms and } \\
\text { coping strategies should be grouped } \\
\text { into five factors. }\end{array}$ \\
\hline \multirow[t]{3}{*}{ Bourgeois-Bougrine, 2003} & 739 airline pilots & $\begin{array}{c}\text { Self-reported } \\
\text { manifestations of fatigue }\end{array}$ & $\begin{array}{l}\text { Night flights and jet lag were the most } \\
\text { important factors that generated } \\
\text { fatigue. The poor quality and quantity } \\
\text { of sleep, together with the long period } \\
\text { of wakefulness before departure, } \\
\text { increased fatigue. }\end{array}$ \\
\hline & 230 & $\begin{array}{l}\text { Samn-Perelli Fatigue } \\
\text { Checklist }\end{array}$ & $\begin{array}{l}\text { The research highlight the importance } \\
\text { of adequate sleep }\end{array}$ \\
\hline & $\begin{array}{l}\text { captains and } 210 \text { first } \\
\text { officers in the Boeing } \\
747-400\end{array}$ & $\begin{array}{l}\text { PalmPilot version of the } \\
\text { psychomotor vigilance } \\
\text { task }\end{array}$ & $\begin{array}{l}\text { during international patterns as well } \\
\text { as the importance of in-flight fatigue } \\
\text { countermeasures. }\end{array}$ \\
\hline Taneja, 2007 & $\begin{array}{l}83 \text { military fast jet } \\
\text { aircrew from the } \\
\text { fighter stream }\end{array}$ & $\begin{array}{c}\text { Self-constructed Fatigue } \\
\text { Questionnaire }\end{array}$ & $\begin{array}{l}\text { Pilots thought that they were able to } \\
\text { operate with full efficiency despite } 1-2 \\
\text { hours' sleep loss. Napping is beneficial. } \\
\text { During the weekend pilots repay } \\
\text { sleep debt. }\end{array}$ \\
\hline
\end{tabular}




\begin{tabular}{|c|c|c|c|}
\hline Gilbert Tong, 2011 & $\begin{array}{l}13 \text { subjects from a } \\
\text { business aviation } \\
\text { company based in the } \\
\text { Asia-Pacific region }\end{array}$ & $\begin{array}{l}\text { Fatigue Risk Management } \\
\text { Systems (FRMS) in } \\
\text { business aviation - } \\
\text { questionnaire }\end{array}$ & $\begin{array}{l}\text { Jet lag, work schedule design, and } \\
\text { fatigue are the most important issues } \\
\text { to business pilots regular job duties }\end{array}$ \\
\hline Conklin, 2012 & $\begin{array}{l}146 \text { airline pilots in the } \\
\text { United States }\end{array}$ & $\begin{array}{l}\text { Self-constructed } \\
\text { questionnaire }\end{array}$ & $\begin{array}{l}\text { Pilots are routinely engage in non- } \\
\text { flight related activities during cruise } \\
\text { flight. These activities help to prevent } \\
\text { boredom, which then helps to } \\
\text { prevent automation complacency } \\
\text { and fatigue. }\end{array}$ \\
\hline Van Drongelen et al., 2013 & $\begin{array}{l}\text { Pilots of all aircraft } \\
\text { types of a large } \\
\text { internationally } \\
\text { operating airline } \\
\text { company }\end{array}$ & $\begin{array}{c}\text { 20-item Checklist } \\
\text { Individual Strength (CIS) }\end{array}$ & $\begin{array}{l}\text { Intervention (tailored advice on } \\
\text { exposure to daylight, sleep, physical } \\
\text { activity and nutrition) can represent } \\
\text { a new and practical tool in fatigue } \\
\text { management. }\end{array}$ \\
\hline Gander et al., 2013 & $\begin{array}{c}\text { Thirty male Captains } \\
\text { and } 40 \text { male First } \\
\text { officers }\end{array}$ & $\begin{array}{l}\text { Karolinska Sleepiness Scale } \\
\text { Samn-Perelli fatigue ratings } \\
\text { A 5-minutes Psychomotor } \\
\text { Vigilance Task }\end{array}$ & $\begin{array}{c}\text { Extended duration of ultra-long range } \\
\text { trips did not lead to a greater pilot } \\
\text { fatigue. }\end{array}$ \\
\hline Wu, 2013 & 74 Boeing 777 pilots & $\begin{array}{l}\text { Psychomotor Vigilance } \\
\text { Task } \\
\text { Subjective rating of } \\
\text { sleepiness and fatigue }\end{array}$ & $\begin{array}{l}\text { Ultra-long range commercial flights } \\
\text { are not more fatiguing than long- } \\
\text { range flights. }\end{array}$ \\
\hline Ma et. al, 2014 & $\begin{array}{l}21 \text { healthy male } \\
\text { juniors student } \\
\text { aviators aged between } \\
20 \text { and } 22\end{array}$ & $\begin{array}{c}\text { FAl test (a fatigue } \\
\text { assessment instrument) } \\
\text { A standing-position } \\
\text { balance test } \\
\text { CFF test (critical flicker } \\
\text { fusion frequency test) }\end{array}$ & $\begin{array}{c}\text { No significant change was observed } \\
\text { in the FAl score. CFF test is the easiest } \\
\text { way to evaluate mental workload to } \\
\text { fatigue. }\end{array}$ \\
\hline
\end{tabular}

Source: Authors

On the basis of the literature review, the study provided answers to research questions:

(1) Which measurements are used to recognize fatigue among pilots?

Tests for measuring fatigue can be divided into two groups, objective tests and subjective tests. Some of the authors used subjective tests for the purpose of their studies, others used objective tests. Measurements used for recognizing fatigue among pilots were discussed in different articles. For example, Ma et al. (2014) evaluated a series of test approaches (subjective and objective reports of fatigue) for pilot performance examination under mental workload conditions and found out that critical flicker fusion frequency (CFF) test was the easiest way to detect mental workload. Taneja (2007) constructed questionnaire for measuring fatigue (about sleep, circadian rhythms, shift work, understanding of fatigue and countermeasures). 20-item Checklist Individual Strength (CIS) measures four dimensions of fatigue; subjective experience of fatigue, reduction 
in motivation, reduction in activity, and reduction in concentration and has good internal consistency (van Drongelen et al., 2013). Gander et al. (2013) used Karolinska Sleepiness Scale and Samn-Perelli fatigue ratings test in their study, because these tests are widely used in the aviation industry and are recommended by ICAO. Psychomotor Vigilance Task was used in both Gander et al. (2013) and Wu (2013) studies. In the study of Gilbert Tong (2011), nine subtopics of Fatigue Risk Management Systems were examined: "working non-traditional hours, fatigue, sleep and napping, food and water, caffeine, drugs, and alcohol, health and well-being, social and family life, work schedule design, and jet lag". For regular job duties, jet lag, work schedule design, and fatigue were important. Conklin (2012) constructed questionnaire on "frequency of non-flight related activities, perceptions of their safety effects, opinions on the activities related to automation complacency, boredom, and fatigue, and general information on the positive and negative outcomes of nonflight related activities". Pilot psychological parameters are mainly evaluated using Samn-Perelli fatigue scale, where response choices are ranged from 1 to $7(1=$ fully alert, wide awake, $2=$ very lively, responsive, but not at peak, $3=$ okay, somewhat fresh, $4=$ a little tired, less than fresh, 5 $=$ moderately tired, let down, $6=$ extremely tired, very difficult to concentrate, $7=$ completely exhausted, unable to function effectively) and Karolinska sleepiness scale. Those psychological tests are quick and easy to administer. In addition, many studies have used both tests which provide data for comparison. The tests mentioned are also widely used in the aviation industry and are recommended by ICAO. Subjective sleepiness is measured with the Karolinska Sleepiness Scale, test of situational sleepiness, where response choices are ranged from 1 to 9 ( $1=$ extremely alert, $3=$ alert, $5=$ neither alert nor sleepy, $6=$ some signs of sleepiness, $7=$ sleepy, no effort to stay awake, $8=$ sleepy, some effort to stay awake, $9=$ very sleepy, great effort to keep awake, fighting sleep). On this scale pilots indicate which level best reflects the psycho-physical state experienced in the last $10 \mathrm{~min}$. It was originally developed to constitute a one dimensional scale of sleepiness and was validated against alpha and theta electroencephalographic (EEG) activity as well as slow eye movement electrooculography (EOG) activity (Akerstedt, Gillberg, 1990).

(2) What are the results of the studies focused on the usefulness of tests for measuring fatigue?

Our aim was to identify the tendencies in the literature about measuring fatigue among pilots. Ma et al. (2014) argued that CFF may become a novel method to evaluate mental workload of pilots, which influences their mental conditions and is the easiest way to evaluate mental workload to fatigue. Petrie and Dawson (1997), using Self-Constructed Fatigue Questionnaire (symptoms, coping strategies of fatigue), suggested that symptoms of fatigue can be grouped into five categories: cognitive dysfunction, sleepiness, emotional disturbance, boredom and physical effects. Also fatigue coping strategies can be grouped into five different categories: active coping, planning energy use, mental withdrawal, communicating with other crew, and drinking coffee. Taneja (2007) demonstrated, as also Naitoh (1992) and Bunting (2016) did, that among aircrew short naps (5-20 minutes) are beneficial. We believe that subjective fatigue of pilots should be measured with the Samn-Perelli Fatigue Scale as Gander et al. (2013) and Renee et al. (2006) suggested. Samn-Perelli fatigue scale is the most sensitive of the subjective fatigue measures. Although the Samn-Perelli scale can be easily administered in the field, the wide range of individual variance limits its efficacy as a once-off assessment tool. 


\section{CONCLUSION}

A wide variety of fatigue measurements are used in different fields. Numerous studies have been conducted for fatigue in the field of aviation, few of them in the field of measuring fatigue among pilots. For this reason, in our study, we have focused on literature review of studies measuring fatigue among pilots.

Practical implication of our study has been to widened the understanding of fatigue measurement among pilots. The contribution of our study is the widened understanding of measurement of pilots' fatigue. This study provides a road map of possible ways for usage of test for pilots' fatigue. The findings can be useful for human resource department planning, for a very important reason, from a risk reduction perspective, to identify fatigue among pilots.

The limitation of this study that can be addressed in some future research is the fact that this research is mainly descriptive in nature. The findings of our research are based on the literature review and meta-analysis. For the purpose of our study, we have used only previously mentioned electronic databases Google Scholar, Emerald, MedLit and Academic Search Complete. Further researches should be focused on deeper investigation of this topic and could include case studies of fatigue with qualitative data.

\section{REFERENCES}

Akerstedt, T. (1995) “Work hours, sleepiness and the underlying mechanisms”, Journal of sleep research, 4(s2), p. 15-22

Åkerstedt, T., Gillberg, M. (1990) "Subjective and objective sleepiness in the active individual", International Journal of Neuroscience, 52(1-2), p. 29-37

Bourgeois-Bougrine, S., Carbon, P., Gounelle, C., Mollard, R., Coblentz, A. (2003) "Perceived fatigue for short-and longhaul flights: a survey of 739 airline pilots", Aviation, space, and environmental medicine, 74(10), p. 1072-1077

Bunting, T. P. (2016) Fatigue mitigation effects of en-route napping on commercial airline pilots flying international routes, North Dakota: The University of North Dakota

Caldwell, J. A. (2005) “Fatigue in aviation”, Travel medicine and infectious disease, 3, p. 85-96

Caldwell, J. A., Mallis, M. M., Caldwell, J. L., Paul, M. A., Miller, J. C., Neri, D. F. (2009) "Aerospace medical association aerospace fatigue countermeasures subcommittee of the human factors committee. Fatigue countermeasures in aviation", Aviation, space and environmental medicine, 80, p. 29-59

Carskadon, M. A., Brown, E. D., Dement, W. C. (1982) "Sleep fragmentation in the elderly: relationship to daytime sleep tendency", Neurobiology of aging, 3(4), p. 321-327

Eriksen, C. A., Akerstedt, T., Nilsson, J. P. (2006) "Fatigue in trans-Atlantic airline operations: diaries and actigraphy for two- vs. threepilot crews", Aviation, space and environmental medicine, 77, p. 605-612

Hatzler, B. M. (2014) "Fatigue on the flight deck: The consequences of sleep loss and the benefits of napping", Accident Analysis \& Prevention, 62, p. 309-318

Federal Aviation Administration (FAA). Regulations, policies: Final rule on pilot fatigue.

Gilbert Tong, C. C. (2011) Fatigue risk management systems in business aviation: the worker's perception on fatigue and its effects, West Lafayette, Indiana: Purdue University 


\section{A. Jerman, M. Meško: How to Measure Fatigue Among Pilots? Zbornik Veleučilišta u Rijeci, Vol. 6 (2018), No. 1, pp. 13-22}

Goode, J. H. (2003) “Are pilots at risk of accidents due to fatigue?", Journal of Safety Research, 34(3), p. 309-313

International Civil Aviation Organization (ICAO). (2011) Fatigue risk management systems manual for regulators, Montreal: ICAO

Lowry, L. C. P. (2012) “Are you tired of fatigue?", The Mobility Forum, Spring, p. 4-7

Ma, J., Ma, R. M., Liu, W. W., Bian, K, Wen, Z. H., Li, X. J. (2014) "Workload influence on fatigue related psychological and physiological performance changes of aviators", PLOS ONE, 9(2), e87121

Mohler, S. R. (1966) "Fatigue in aviation activities", Aerospace Medicine, 37, p. 722-732

Naitoh, P. (1992) Minimal sleep to maintain performance: the search for sleep quantum in sustained operations, Boston: Birkhauser

Petrie, K. J., Dawson, A. G. (1997) "Symptoms of fatigue and coping strategies in international pilots", The international journal of aviation psychology, 7(3), p. 251-258

Petrie, K. J., Powell, D., Broadbent, E. (2004) "Fatigue self-management strategies and reported fatigue in international pilots", Ergonomics, 47, p. 461-468

Powell, D., Spencer, M. B., Holland, D., Broadbent, E., Petrie, K. J. (2007) “Pilot fatigue in short-haul operations: Effects of number of sectors, duty length, and time of day", Aviation, space, and environmental medicine, 78(7), p. 698-701

Powell, D., Spencer, M. B., Holland, D., Petrie, K. J. (2008) "Fatigue in two-pilot operations: implications for flight and duty time limitations", Aviation, space, and environmental medicine, 79(11), p. 1047-1050

Taneja, N. (2007) "Fatigue in aviation: A survey of the awareness and attitudes of Indian air force pilot", The international journal of aviation psychology, 17(3), p. 275-284

vanDrongelen, A., van der Beek, A. J., Hlobil, H., Smid, T., Boot, C. R. L. (2013) "Development and evaluation of an intervention aiming to reduce fatigue in airline pilots: design of a randomised controlled trial", BMC Public health, 13, p. $776-784$

Wu, L. J. (2013) Evidence based fatigue risk management during 24/7 operations: objective assessment of pilots' sleep, performance, and fatigue during ultra long range and long range flights, Washington: Washington State University, Department of Psychology 


\section{KAKO MJERITI UMOR PILOTA ? 3}

\section{SAŽETAK}

Umor predstavlja velik problem u zrakoplovstvu, stoga je važno rano prepoznati umor pilota prije nego što se dogodi nezgoda ili nesreća. Cilj našeg istraživanja bio je dati pregled literature koja se bavi mjerenjem umora pilota, saznati koja se mjerenja koriste kako bi se prepoznao umor te koji su rezultati provedenih istraživanja s obzirom na to koliko su korisni testovi za mjerenje umora. Rezultati se zasnivaju na metaanalizi. U našem istraživanju koristili smo sljedeće elektroničke baze podataka: Google Scholar, Emerald, MedLit and Academic Search Complete. Koristili smo analizu sadržaja radova kako bismo dobili pregled kvalitativnih podataka i usporedili ih. Dobiveni rezultati pokazuju da se testovi za mjerenje umora pilota mogu podijeliti u dvije grupe: objektivni i subjektivni testovi. Subjektivni umor pilota uglavnom se procjenjuje primjenom Samn-Perelli skale umora, koja se uvelike koristi u zrakoplovnoj industriji, a pruža podatke za usporedbu. Doprinos ovog istraživanja je proširenje razumijevanja mjerenja umora pilota i korisnost ovih mjerenja među pilotima. Rezultati našeg istraživanja su deskriptivne naravi. Daljnja istraživanja trebala bi se usredotočiti na dublja istraživanja ove teme te bi mogla uključiti i studije slučaja umora među pilotima s kvalitativnim podacima.

Ključne riječi: piloti, umor, mjerenje umora, testovi, upravljanje ljudskim resursima

1 Magistar managementa, Ljubljanski potniški promet d.o.o., Celoveška cesta 160, 1000 Ljubljana, Slovenija.

E-mail: andrej.jerman@lpp.si

2 Dr. sc., izvanredni profesor, University of Primorska, Faculty management, Cankarjeva 5, 6000 Koper, Slovenija.

E-mail:maja.mesko@fm-kp.si

Datum primitka rada: 1. 11. 2017.; datum prihvaćanja rada: 15. 12. 2017. 
